\title{
The influence of direct payments on farmers' hail insurance decisions
}

\section{Journal Article}

Author(s):

Finger, Robert (iD; Lehmann, Niklaus

Publication date:

2012-05

Permanent link:

https://doi.org/10.3929/ethz-b-000048438

Rights / license:

In Copyright - Non-Commercial Use Permitted

Originally published in:

Agricultural Economics 43(3), https://doi.org/10.1111/j.1574-0862.2012.00587.x 


\section{Postprint}

This is the accepted version of a paper published in Agricultural Economics. This paper has been peerreviewed but does not include the final publisher proof-corrections or journal pagination.

\section{Citation for the original published paper:}

Finger, R., Lehmann, N. (2012). The Influence of Direct Payments on Farmers' Hail Insurance Decisions. Agricultural Economics. 43(3): 343-354

https://doi.org/10.1111/i.1574-0862.2012.00587.x

Access to the published version may require subscription.

N.B. When citing this work, cite the original published paper 


\title{
The Influence of Direct Payments on Farmers' Hail Insurance Decisions
}

\author{
Authors: Robert Finger, Niklaus Lehmann
}

\begin{abstract}
We analyze determinants of hail insurance use of Swiss farmers, using FADN panel data covering the period 1990-2009. Mixed effect logistic regression models are estimated to identify the most important farm and farmer characteristics that trigger insurance use. In addition, information on local hail risk is taken into account in these models. It shows that larger farms, with specialization in crop production, and with larger local hail risks are more likely to adopt the hail insurance. Moreover, insurance users are usually older and better educated. Since the early 1990s, Swiss agricultural policy has reduced price support and introduced general and ecological direct payments. This has led to a much higher importance of direct payments for farmers' incomes. Our analysis shows that this development has contributed to decreasing hail adoption rates in Switzerland in the considered period. Thus, our results indicate that the larger the share of direct payments for total farm revenue, the less attractive are insurances as risk management strategy for farmers. This interdependency should be explicitly considered by agricultural policy in the design of support mechanisms.
\end{abstract}

\section{JEL Codes: Q1, D0, G2}

Keywords: Hail insurance, demand, adoption determinants, direct payments, Switzerland 


\section{Introduction}

Risk management is expected to gain importance in agriculture (e.g. Musshoff et al., 2011, Bielza Diaz-Caneja et al., 2008), in particular due to increasing production risks caused by changes in climatic conditions (e.g. Torriani et al., 2008) as well as due to increasing price volatility caused by market liberalization (e.g. Mahul, 2003). In order to cope with these risks, insurances may play an even more critical role as risk management tool for farmers. This is particularly the case for European agriculture. Unlike in North-America, no widespread use of different insurance options such as farm-revenue, farm-yield or index based insurances can be currently observed in Europe at large (Bielza Diaz-Caneja et al., 2008). In contrast, hail (and combined peril) insurances have a long tradition in European agriculture and are still the most used insurance scheme in Europe. Thus, farmers' current decisions with respect to the use of hail insurance may be a good indicator for problems, potentials and pitfalls of other agricultural insurance schemes. More specifically, factors that influence insurance use are important to project the potential use of other agricultural risk management instruments in the future. Furthermore, an analysis of current insurance decisions of farmers can reveal potential policy measures to support farm-level risk management strategies. An empirically-founded advice for agricultural policy maker is of particular importance because improving on-farm risk management is an explicit goal of agricultural policies in many countries (e.g. Bielza Diaz-Caneja et al., 2008, Garrido and Zilberman, 2008, Enjolras and Sentis, 2011, Sherrick et al., 2004).

Literature overviews and case studies on the adoption of agricultural insurances are provided, for instance, by Sherrick et al. (2004), Medina et al. (2010), Rydant (1979), Enjolras and Sentis (2011), Jung et al. (2005), Cabas et al. (2008), Ogurtsov et al. (2006), Garrido and Zilberman, (2008). These analyses show that the adoption of agricultural insurances is usually determined by a wide 
range of factors. Among these factors that influence farmers' use of insurances are farm and farmer characteristics (such as farm size, farmers' education and age), the composition of farm income (e.g. the importance of off-farm income), production risks (e.g. local climate conditions), employed production techniques (e.g. irrigated vs. rainfed production), the monetary value of farm production (e.g. expected yield and output price levels) as well as the price of the insurance premium and governmental insurance support (e.g. subsidies for insurance premiums).

In this empirical literature on insurance adoption, the effects of direct payments and off-farm employment on the use of insurance have, however, not been considered so far explicitly. As an exception, the recent study of Chakir and Hardelin (2010) has shown that subsidies negatively affected insurance demand in rapeseed production in the Departement of Meuse (France). In a recent paper, Enjolras and Sentis (2011) furthermore indicate a lack of micro-level analyses of insurance decisions as well as a lack of studies that directly integrate climatic sources of agricultural production risks in these analyses. Moreover, existing studies often focus on single years (e.g. Sherrick et al., 2004) or short time periods (e.g. Enjolras and Sentis, 2011) as well as are often limited to specific agricultural sectors (e.g. Jung et al., 2005, Ogurtsov et al., 2006, Medina et al., 2010).

In this article, we contribute to filling these gaps by analyzing the determinants of hail insurance use on a large scale over a long time-horizon, i.e. for Swiss agriculture at large covering the period 1990-2009. Furthermore, hail risk is considered in our analysis spatially explicitly. Most importantly, the effects of both direct payments and off-farm employment on insurance adoption are estimated and quantified in our analysis. This particular focus is motivated by the fact that both direct payments and off-farm income have become much more important for agricultural income in Swiss agriculture in the last decades (El Benni et al., 2011). Due to this development, Swiss 
agriculture is a good case study to investigate the effect of these two income components on farmers' risk management behavior.

Following Hennessy (1998), this is expected to be relevant for two reasons. First, and most importantly, such non-volatile income sources reduce the variability of total farm income, i.e. they have an insurance effect. Thus, these income sources decrease the probability that farmers' face very low income levels and are thereby substitutes for agricultural insurances. Moreover, direct payments and off-farm income might increase farmers' wealth ${ }^{1}$. If farmers are risk-averse, such increase in their wealth level is expected to decrease their level of risk aversion (wealth effect). This decrease in risk aversion finally reduces farmers' demand for insurances. Wealth and insurance effects of non-volatile income sources are defined and discussed in Hennessy (1998) and Femenia et al. (2010). Bhaskar and Beghin (2009) provide an overview of the literature on insurance and wealth effects of direct payments, which shows that insurance effects are much more relevant than wealth effects. This is particular the case if policy changes that have simultaneous price (reducing) and payment (increasing) effects that offset each other as it has been observed in Switzerland (Sckokai and Moro, 2006). Along these lines, Koundouri et al. (2009) show that agricultural policy reforms in Finland towards decoupled direct payments have affected farmer' risk attitudes, particularly decreasing risk aversion. Though the above mentioned literature focuses on the effects of direct payments, off-farm income is assumed to have similar (in particular insurance) effects (e.g. Reardon et al., 2000).

In summary, we expect that the increasing relevance of both direct payments and off-farm income, i.e. of weather and hail independent income sources, that have been observed in Switzerland

\footnotetext{
${ }^{1}$ This assumes that direct payments and off-farm income remain with the farmer (i.e. increase his wealth) and are not passed through to, for instance, land owners (Femenia et al., 2010). In Switzerland, there are legal limitations on maximum land rents, i.e. additional income mainly remains with the farmer which enables a wealth effect (see Häusler, 2010 , for details).
} 
decreases farmers' incentives to use the hail insurance. To investigate this hypothesis, this article analyses the determinants of hail insurance adoption in Swiss agriculture ${ }^{2}$. To this end, different logistic regression analyses are conducted based on a unique combination of long-term Farm Accountancy Data Network (FADN) panel data with explicit information on local hail risks. Using this setup, the effects of direct payments and off-farm income on insurance adoption are tested and quantified.

Though the here presented example focuses on Swiss agriculture, we expect that our results are highly relevant for other countries. In particular, countries of the European Union consider the integration of risk management in the Common Agricultural Policy (CAP), and several countries already support agricultural insurance schemes (Bielza Diaz-Caneja et al., 2008, Garrido and Zilberman, 2008). However, the CAP is also characterized by shifts from price support to a further relevance of direct payments as well as by increased incentives for off-farm employment (e.g. Ackrill et al., 2008, Woldehanna et al., 2000). Thus, the effects of direct payments and off-farm income on insurance adoption observed in Switzerland, where both direct payments and off-farm income are substantial determinants of farm income, may be a prospect for potential developments in the European Union.

\section{Background}

The here presented analysis focuses on the farm-level use/non-use of hail insurance. The choice of a farm-level (and not crop specific) analysis is motivated by the fact that though Swiss farmers can purchase hail insurance for single crops, the most important hail insurance scheme covers the

\footnotetext{
${ }^{2}$ Note that it is not the goal of our analysis to directly estimate farmers' risk aversion, which is beyond the scope of this paper but should be addressed in future research.
} 
entire farm ${ }^{3}$. Thus, our analysis focuses on the binary choice variable insurance use at the farmlevel.

Figure 1a shows the development of the overall hail insurance adoption rates from 1990 to 2009 within Swiss agriculture (based on FADN data). This participation rate shows a decreasing trend over time, from $69 \%$ in 1990 to $56 \%$ in 2002, but re-increased to about $60 \%$ in 2004 and shows slight reductions over time henceforward. This study aims to link this development of decreasing hail insurance use with contrary developments in the relevance of direct payments and off-farm income that are displayed in Figures $1 \mathrm{~b}$ and $1 \mathrm{c}$.

The developments of direct payments and off-farm income are caused by changes in the agricultural policy in Switzerland. This development was particularly emphasized in two major reform steps in 1992 and 1999 (El Benni et al., 2011). Prior 1992, subsidies to farmers were mainly based on market, i.e. price, support. In 1992, decoupled direct payments were introduced particularly for agri-environmental schemes that aim to promote environmental-friendly production systems and can be adopted by farmers on a voluntary basis. In the next major reform step in 1999, general and ecological direct payments were introduced. The receipt of general direct payments requires the fulfillment of cross-compliance measures that comprise baseline criteria regarding environmental and animal friendly production (El Benni et al., 2011). On the top of these cross-compliance obligations, farmers can apply for additional agri-environmental programs to receive ecological direct payments. Throughout the 1990s, price support was continuously reduced with introduction of decoupled direct payments schemes. Since the last reform step in 1999, no considerable changes in agricultural policy and supporting schemes have been made. For

\footnotetext{
${ }^{3}$ This includes the entire arable land (and/or grassland) surface of a farm, with a general (i.e. not crop specific) premium. In this hail insurance scheme, larger shares of vulnerable crops such as vegetables require higher premiums, see www.hagel.ch for details.
} 
overviews and descriptions of agricultural policy reform steps in the last decades in Switzerland, see El Benni and Lehmann (2010), El Benni et al. (2011) and Mann (2003). In contrast to the experience of other (e.g. European) countries (e.g. Garrido and Zilberman, 2008, Enjolras and Sentis, 2011), the support of risk management tools is not in the focus of Swiss agricultural policy. For instance, the Swiss government has stopped premium subsidies for the hail insurance in 1967 (LID, 2005), and also other insurance products are not subsidized because governmental support to farmers is expected to be a sufficient risk management support (BLW, 2011). Note that Swiss hail insurance contracts usually include also other elementary risks (of lower relevance) such as flooding or storm damages. In addition, products that include insurance against damages from droughts and heavy rainfalls are available, but the here analyzed hail insurance has by far the highest relevance for farmers (see e.g. Finger and Calanca, 2011, for discussions).

As a result of the above described policy reforms, direct payments are currently one of the most important tools of agricultural policy in Switzerland, which is also reflected in the developments shown in Figure 1: The importance of direct payments (measured as share on total farm revenue) increased continuously over time, rising from 7\% in 1990 to $29 \%$ in 2009 (Figure 1b). Also the relevance of off-farm income for total farm revenue increased over time (Figure 1c): while about $9 \%$ of total farm revenue have been generated from off-farm income in 1990, this share accounts for about $14 \%$ in 2009 . Due to the reduction of (governmental) price support over time, the importance of income generated on agricultural markets has decreased over the last two decades (El Benni et al., 2011). These contrasting developments of different income sources are captured in our analysis by the here applied definition of the share of direct payment and off-farm income to total farm revenue. Figure 1d shows that the total farm size increased from about 18 ha in 1990 
to 22 ha (i.e. by about $22 \%$ ) in 2009 , while the average size of arable land increased (only) from 7.7 ha to about 8.6 ha (i.e. by about $12 \%$ ) in the period $1990-2009^{4}$.

Rydant (1979) argues that the participation in hail insurance schemes is directly linked to recent perception of hail damages. This means, a decreasing hail insurance adoption rate might be caused by low frequencies of hail events in previous years. However, this effect cannot explain decreasing adoption rates shown in Figure 1a, because Schiesser (2003) shows that the frequency of significant hail events in Switzerland increased from 1980 to 1994, but decreased till 1999. But, the frequency of hail events explains the upward jump of the adoption rate in 1995, i.e. adoption increased sharply after one of the most important 'hail years' in Switzerland in 1994 (Schiesser, 2003). In contrast, the deviations of the adoption rate in the years 2002 and 2003 from the underlying trend (Figure 1a) cannot be directly linked to hail event frequency, because in these years no exceptional frequency of significant hail events has been observed (Schiesser and Schmid, 2005). However, we expect that these deviations are due to general changes in the sampling methodology for the here used FADN data in this period, which also affected other variables (e.g. farm size, specialization, age) in the sample (cp. Meier, 2005).

Another reason for changes in hail adoption rates might be the subsidization of insurance premiums. As indicated above, there is no governmental subsidization of hail insurances in Switzerland, but subsidization takes place at the cantonal level. However, the amount of premium subsidies is negligible because these subsidies covered (on average) only $2 \%$ of total hail insurance premiums in the early 1990s and $0.03 \%$ in 2009 (SBV, 2010), paid only by selected cantons, which

\footnotetext{
${ }^{4}$ The smaller growth of average arable land sizes can be explained with the fact that Swiss agricultural policy reforms gave incentives to increase grassland areas at the expense of arable land.
} 
represent only a small fraction of farms in Switzerland ${ }^{5}$. Thus, though cantonal premium subsidies for the hail insurance declined during the last decades, they are not explicitly considered in our analysis.

The trends presented in Figure 1, clearly underpin the hypothesis that the adoption of hail insurance may be related to the increasing importance of direct payments and off-farm income ${ }^{6}$. However, several other factors that also influence the adoption decision have to be considered before such conclusions can be drawn ${ }^{7}$. In particular, factors such as farm size, local hail risk, main farm activities (crop or livestock production), age and education have to be taken into account, because these variables have been also changing over time, for instance, due to structural change in Swiss agriculture. Thus, an econometric approach is used to control for other influential factors of hail insurance adoption at the farm level.

$<$ Figure 1. Development of hail insurance adoption, the share of direct payments and off-farm income to total farm revenue as well as of farm size and arable land, 1990-2009 >

\section{Methodology}

In order to identify the most important factors that influenced the hail insurance adoption decision, we use logistic regression analyses taking different explanatory variables into account. These

\footnotetext{
${ }^{5}$ The cantons that pay currently premium subsidies are Appenzell Innerrhoden, Basel Land, Nidwalden, Schwyz and Zug (LID, 2005). The respective subsidization follows cantonal law, for instance, the canton of Schwyz pays a premium subsidy of $10 \%$ to all participants.

${ }^{6}$ This "first glance" hypothesis is also underlined by high correlations between the displayed mean values for the shares of direct payments and off-farm income to total farm revenue and mean adoption rates (-0.91 and -0.86 , respectively).

${ }^{7}$ Conceptual models on insurance use are presented by Cabas et al. (2008) and Sherrick et al. (2004), which are omitted here to avoid repetition.
} 
explanatory variables as well as associated hypotheses with regard to their influence on insurance adoption are presented in Table 1. Variables and hypotheses are based on a review of empirical and theoretical insurance adoption literature. For the logistic regression analyses, two strategies are applied: First, group comparisons and logistic regressions are conducted for specific years independently. This identifies differences between adopters and non-adopters for specific years, shows their development over time and reveals if determinants for insurance use changed over time. Second, the panel structure of the data is used - i.e. the development of a specific farm is taken into account - using a generalized linear mixed model specification.

$<$ Table 1. Definition of Variables and Associated Hypotheses >

In a first step, adopters and non-adopters of the hail insurance are compared with each other for specific years. In this comparison, the variables that are summarized in Table 1 are taken into account and the Mann-Whitney test is used to assess the significance of differences between the two groups. Subsequently, a binary logistic regression is employed. In this regression, let $A$ be the binary response variable of hail insurance use, i.e. $A_{i} \in\{0,1\}$, for $\mathrm{i}=1, \ldots, \mathrm{n}$ farms, with $\pi_{i}$ being the expectation that $A_{i}=1$ (i.e. that farm $\mathrm{i}$ is an adopter) given $X_{i}$. In binary logistic regression this response probability is modeled as follows:

$$
\log \left(\frac{\pi_{i}}{1-\pi_{i}}\right)=\alpha+\beta X_{i}+\epsilon_{i}
$$

$\frac{\pi}{1-\pi}$ represents the odds of response $A=1$ given $X, \alpha$ is the vector of model intercept, $\beta$ is the vector of regression coefficients and $\varepsilon$ the vector of error terms. 
For these (simple) logistic regressions, three years have been chosen: 1990 (pre-reform), 1999 (post-reform), and 2008 (recent), as outlined in the policy background presented above. These regression results are used to estimate and visualize the marginal effects of changes in different explanatory variables. To this end, estimated (ceteris paribus) responses in the probabilities for hail insurance adoption for changes in different explanatory variables, where all other explanatory variables are set to their sample means are presented. These marginal effects are displayed for the variables farm size, education, specialization on crop production, hail risk, off-farm income and direct payments using the estimated coefficients of the logistic regression models for 1990, 1999 and 2008, respectively.

The above described logistic regressions for separated years focus on the differences between farms and farmers. For instance, these analyses assume that observed differences in insurance use are caused by differences in the explanatory variables (e.g. the farm size, age and education) across farms. Therefore, this approach does not account for changes of explanatory variables over time at a specific farm. Furthermore, many unobserved (farm-level) factors that trigger adoption are not considered.

To overcome this drawback, we use a generalized linear mixed model, which takes the within farm effects as well as the between farm effects into account (see Johnston and DiNardo, 1997, for details). Thus, the panel structure of the data is $u_{s e d}^{8}$. In contrast to the simple logistic regression presented in Equation 1, we now consider observations from $i=1, \ldots, n$ farms and for $t=1, \ldots, T$ years. The generalized linear mixed model can be formulated as follows:

\footnotetext{
${ }^{8}$ Note that ignoring the panel structure of the dataset by using normal logistic regression over the entire set of observations would understate standard errors (Johnston and DiNardo, 1997).
} 


$$
\log \left(\frac{\pi_{i t}}{1-\pi_{i t}}\right)=\alpha+a_{i}+\beta X_{i t}+\epsilon_{i t}
$$

Most importantly, the term $a_{i}$ captures all (observed and unobserved) time invariant characteristics of farm i (individual effects for each farm), while the regression coefficients $(\beta)$ are assumed to be equal over all farms.

In order to validate the explanatory power of all estimated logistic regression models, we conduct cross-validations (see e.g. Efron and Gong, 1983, for details) with a randomly selected training data sets consisting of $50 \%$ of the observations and validation datasets of the remaining observations. The coefficient estimates derived from the training dataset are used to predict hail insurance adoption in the validation dataset. This cross validation procedure is repeated 1000 times for each of the here presented regression models and the average percentages of correct predictions are reported.

\section{Data}

The here presented analysis is based on Swiss FADN data, i.e. farm level bookkeeping data, covering the period 1990-2009 (Dux and Schmid, 2010) ${ }^{9}$. Relevant for this study, this database documents expenditures on hail insurance for each farm and year ${ }^{10}$. The used FADN data sample has in total, i.e. over 20 years, 66438 observations that come from in total 9622 different farms ${ }^{11}$. Most observations are available for the year $1990(\mathrm{~N}=4008)$ and the lowest number of observations

\footnotetext{
${ }^{9}$ Note that the representativeness of the Swiss FADN data is limited due to the sampling methods applied (Meier, 2005).

${ }^{10}$ The farm- and contract-specific premium levels as well as the actual claims are not available to our analysis.

${ }^{11}$ Note that the length of individual farm records differs, i.e. the panel is unbalanced. More specifically, 1386 farms have only a single observation and 1253 have two observations in the sample, while 155 farms have continuous records over the entire 20 years.
} 
is available for $2002(\mathrm{~N}=2067)$. The low number of available observations for the early 2000s was caused by changes in the FADN data sampling methodology (see Meier, 2005, for descriptions). Note that these changes in the sampling methodology mainly affected the structure of farms selected and are thus (implicitly) taken into account in the here presented regression analyses. Information on local hail risk is taken from the Swiss hail insurance and is defined as the number of years with insured hail damages for each municipality in the period 1961-2004 ${ }^{12}$. This dataset is a unique source to approximate hail risks spatially explicitly. This spatial distribution of hail hazards in Switzerland is shown in Figure 2. It shows that hail hazard (i.e. hail risk) is highly heterogeneous and that in particular pre-Alpine regions face high hail risks. The FADN data and the hail risk data are matched over the farms' municipalities.

$<$ Figure 2. Hail hazards in Switzerland in the period 1961-2004>

Figure 3 shows the spatial distribution hail insurance participation rates as well as the relevance of direct payments (to total farm revenue, cp. Table 1) in the years 1990 and 2008. Note that these data are aggregated at the district level in Figure 3 to ensure that sufficient observations are available for each cell. It shows that hail adoption rates reduced over time (cp. also Figure 1) and that there has been a regional shift in hail insurance use. The latter observation is expected to be caused by structural change, which led to adjustments in farm programs in specific regions (e.g. changing from milk to crop production). Figure 3 shows furthermore that the relevance of direct payments for total farm revenue increased from 1990 to 2008 in Switzerland at large. Comparing Figure 2 and 3, one can see that regions with high hail risks tend also to have higher hail insurance

\footnotetext{
${ }^{12}$ This information is available from the Swiss hail insurance at http://www.hagel.ch/fileadmin/hagel/dat/3052a.pdf (assessed March 8, 2011).
} 
adoption rates. Furthermore, regions with high shares of direct payments to total farm revenue tend to have lower hail insurance adoption rates, though there is no clear cut relationship observable, particularly for high hail risk regions.

$<$ Figure 3. Spatial distribution of hail insurance adoption rates and the share of direct payments to total farm revenue in the years 1990 and $2008>$

\section{Results}

Table 2 shows variable means for user- and non-user of the hail insurance in the years 1990, 1999 and 2008. In all years, users are characterized by larger farms, a larger size (and share) of arable land as well as a higher specialization in crops and special crops. The results for land tenure show that users tend to have less rented land (i.e. are more tenured). Furthermore, hail insurance users are older and better educated. We also find the expected effect of hail risks on insurance adoption: users (or more precisely, their municipalities) faced more often hail occurrence in the period 19612004. Moreover, users generated less revenue from off-farm income and direct payments.

$<$ Table 2. Mean of Farm and Farmer Characteristics of Insurance Users and Non-Users in 1990, 1999 and $2008>$

Multicollinearity problems prevent a logistic regression analysis based on the (full) set of variables presented in Table 2. In particular, the variables arable land, share of arable land and farm size are significantly positively correlated with each other. Thus, the variables arable land and share of arable land have been omitted from the regression analyses. Moreover, the variable share of special 
crops has been removed due to high positive correlation with the (general) specialization in crop production.

<Table 3. Results from the Logistic Regressions for the Years 1990, 1999 and 2008.>

The results of the logistic regressions are presented in Table 3. Coefficient estimates are presented throughout this article as odds ratio and represent the estimated changes in the odds of insurance adoption that is caused by a one unit increase in the respective explanatory variable and holding all other variables fixed at their mean values. For instance, an increase of the farm size by 1 ha in the 1990 model, would increase the odds that a farm uses the hail insurance by $2.9 \%$. In contrast, a $1 \%$ increase of the share of direct payments on total farm revenue decreases these odds by about $4.2 \%(1 / 0.960-1)$.

Unlike to the group comparisons (Table 2), the logistic regression results presented in Table 3 show that off-farm income does not significantly contribute to the explanation of the adoption decision in any of the three models ${ }^{13}$. The variable age is only significant in the 1999 model, showing that insurance users tend to be older. Land tenure is significant in the models for 1990 and 2008, indicating that land tenure increases the adoption probabilities. However, land tenure is negatively correlated with farm size, i.e. larger farms tend to rely more on rented land in Switzerland. For 1990, 1999 and 2008, the correlations between farm size and land tenure are $0.14,-0.25$ and -0.24 , respectively. Removing farm size from the logistic regression models does not change the estimated effects for land tenure but reduces the level of significance for this

\footnotetext{
${ }^{13}$ To validate that this result is not caused by multicollinearity with the variables farm size and specialization on crop production, we re-estimated the models with either of these variables being removed. No change in the direction and significance of the effect has been found.
} 
variable (only significant at the $10 \%$ level in 1990). Estimated effects and significances for other variables do, however, not change if farm size is removed from the models. Thus, results for land tenure derived in these models remain inconclusive and have to be interpreted with care.

The variables farm size, hail risk, specialization in crop production as well as the share of direct payments significantly explain the adoption behavior in all three models. More specifically, larger farms, farms that are more specialized in crop production and those farms that face higher hail risks are more likely to use hail insurance. In contrast, a higher dependency on direct payments for total farm revenue decreases the probability that a farm uses hail insurance. Furthermore, we find a positive effect of education on the adoption probability for the 2008 model. Table 3 shows that the absolute coefficient estimates, i.e. the effects of explanatory variables on hail insurance use, remain stable over time. Thus, no structural changes in the determinants of hail insurance use could be observed over time.

Figure 4 shows the marginal effects of farm size, specialization on crop production, hail risk, education as well as off-farm income and direct payments on the probability of hail insurance adoption. To estimate marginal effects, all other variables are set on their sample mean. The displayed results are based on the 3 models presented in Table 3. It shows that particularly farm size and the specialization on crop production have very strong positive effects. If, for instance, the specialization on crop production approaches $100 \%$ in the 2008 model, the adoption probability approaches $99 \%$. In contrast, an increasing share of direct payments decreases the hail insurance adoption probabilities. The adoption probabilities fall from about $80 \%$ to about $47 \%$ if the share of direct payments is increased from 0 to $50 \%$ (and all other variables are set on their sample mean) in the 2008 model. Figure 4 shows furthermore that changes in the share of off-farm income, the education level as well as in the hail risk do not have large effects on hail insurance adoption 
probabilities. Figure 4 reveals differences between years regarding the marginal effects of farm size, hail risk and direct payments. Interestingly, it shows that the actual hail risk as well as direct payments were more important for the adoption decision (i.e. the response curves are steeper) in the 1990 model than under current conditions. In contrast, the influence of farm size on hail insurance adoption was smaller (i.e. the response curve was flatter) in the 1990 model than in the 1999 and 2008 regression models.

For the estimation of the panel-data (mixed effect) logistic regression model, we used the same set of variables presented above for single year logistic regressions. However, some modifications in the set of explanatory variables have been necessary: Education is not included in the panel regression because it is not available before 2003. Moreover, farmer's age is usually linearly increasing over time. Thus, this variable does not contain the desired variability over time and is excluded from the regression analysis. In addition, multicollinearity problems motivated the estimation of three different models where either the variable farm size, specialization in crop production or no variable is omitted.

Due to missing values, the variable land tenure reduces the sample size by 7988 observations ( 852 farms). The regression has been conducted with and without the variable land tenure. Land tenure is not significant in any of the models. The qualitative interpretation of the other coefficient estimates remains unaffected by the inclusion of this variable. To ensure clarity, only model specifications without land tenure are displayed in Table 4. Note that the logistic regression based on panel data includes a dummy variable for the year 1995, i.e. the year after a major hail event (Schiesser, 2003) which is expected to increase hail insurance adoption rates in the subsequent year (Rydant, 1979). 
<Table 4. Results from the Logistic Regression Using Panel Data 1990-2009>

The results of the mixed effect logistic regression that considers all farms over the period 19902009 are shown in Table 4. As indicated before, an increasing farm size as well as an increasing specialization in crop production leads to a higher probability that a farm uses hail insurance. Moreover, the observed hail frequency determines the adoption of hail insurance. Thus, the higher the observed 'risk' of hail damages, the higher is the hail insurance adoption probability. The shares of off-farm income and direct payments to total farm revenue show the expected effect, i.e. they reduce the probability of insurance adoption. The larger the share of farmers' income that is generated from non-agricultural (and hail independent) sources, the lower is the incentive to use hail insurance as a risk management strategy. The dummy for the year 1995 is positive and significant in all 3 models. Thus, adoption rates significantly increase if severe hail damages have been observed in the previous year.

Note that education was not considered in these models because it is only available since 2003. In order to test if this omission caused biases in the regression results, the mixed effect logistic regression was re-estimated for the period 2003-2009 taking education into account. The results of these regressions are presented in Table 5 and show no differences in the sign, significance and magnitude of estimated coefficients to the model estimated over the entire period (Table 4). However, a positive, significant influence of education on hail insurance adoption is indicated.

\section{Discussion and Conclusion}


We analyze determinants of hail insurance use in Swiss agriculture using FADN data for the period 1990-2009. In agreement with insurance adoption research in other countries, we find that larger farms that are more specialized in crop production (and the production of special crops) are more likely to use hail insurance (e.g. Rydant, 1979, Sherrick et al., 2004). Farms with a specialization in crops, or even in special crops such as fruits and vegetables, have a higher vulnerability to hail damages, compared e.g. to a grassland producer. This is due to a higher monetary value per area unit of their production and due to the higher hail sensitivity of these crops itself (e.g. Wixon, 2005). Our analysis also shows that insurance users tend to be older and better educated, which is explained by a 'greater precision in risk assessment' by these farmers (Sherrick et al., 2004). Because the risk of hail occurrence is heterogeneous across Switzerland, our analysis also considered the risk of local hail occurrence. It shows that farms located in risky areas are more likely to adopt hail insurance, which is in agreement with hypotheses developed in other studies (e.g. Rydant, 1979).

Finally, we analyze if the increasing importance of direct payments and off-farm income (both measured as share to total farm revenue) had an influence on the use of hail insurance. This hypothesis is motivated by the fact that these (weather- and hail-independent) income sources have an insurance effect (i.e. reduce the variability of total farm income) as well as a wealth effect (an increasing income reduces risk aversion) (cp. Hennessy, 1998). The importance of direct payments and off-farm income has increased remarkably in Switzerland within the last two decades, particularly due to agricultural policy reforms that reduced price support and introduced decoupled direct payments. Thus, both increasing direct payments and off-farm employment as well as price reductions are expected to have contributed to these developments. Our analysis demonstrates that in particular the increasing share of direct payments to total farm revenue contributed significantly 
to the observed reduction of hail insurance use. The variable off-farm income was not in all models significant. Analyzing the marginal effects of these variables on the probabilities of insurance adoption underlined the particular relevance of direct payments on hail insurance adoption rates, while off-farm income had only a very small impact. We are aware that these relationships can be also assigned to the decrease of price levels over time, which goes hand in hand with the development of the other variables.

Our analysis thus indicates that if output prices decrease further and in particular direct payments gain further importance, a declining participation rate in the Swiss hail insurance scheme is expected. This also means that farmers' risk management will rather rely on governmental support than on insurances. Thus, even though climate change and market liberalization (e.g. Torriani et al. 2008, Finger et al., 2010, 2011, Mahul, 2003) will increase production and price risks in the future, the increasing importance of non-agricultural production income sources may limit the potential of agricultural insurances in Switzerland. Given the developments of the common agricultural policy of the European Union, which is characterized by an increasing importance of direct payments (e.g. Ackrill et al., 2008), the results found for Switzerland may also be evident for other European countries.

To address several effects that have been indicated in this article in more detail, further research is needed. In particular, we think that changes in explanatory variables such as farm size, age and education have to be investigated. Thus, the effects of farm size expansion, e.g. due to land buying (Mann, 2005), and farm transfer to farm successors (Mann, 2007) on hail insurance decisions should be analyzed. Furthermore, the adoption of agri-environmental programs (e.g. Finger and El Benni, 2011) that implies higher (ecological) direct payments, but decreases per hectare croprevenues is expected to affect insurance demand. In future research, also the role of financial 
characteristics of farms (e.g. liquidity and debt indicators) on farmers' risk management strategies should be emphasized (Enjolras and Sentis, 2011).

The here presented results indicate that direct payments reduce farmers' insurance demand. Thus, the increasing importance of this income component should be considered if the impacts of increasing production risks on future insurance demand are assessed. Furthermore, this relationship points out contradicting influences of agricultural policy measures. Several countries pay decoupled direct payments to farmers but also subsidize insurances and many countries aim to further improve and support agricultural risk management measures (e.g. Bielza Diaz-Caneja et al., 2008, Garrido and Zilberman, 2008, Enjolras and Sentis, 2011, Sherrick et al., 2004). However, these two policy measures seem to exclude each other at least partially: The higher the level of direct payments, the more subsidies will be required to induce insurance adoption by farmers. Thus, agricultural policy should explicitly consider the interdependency of these policy measures.

\section{Acknowledgements}

This work was supported by the Swiss National Science Foundation in the framework of the National Centre of Competence in Research on Climate (NCCR Climate) and the National Research Programme 61. We would like to thank the Agroscope Reckenholz-Tänikon Research Station and the Swiss Hail Insurance for providing the FADN and the hail risk data. Furthermore, we gratefully acknowledge comments and suggestions from the editor, two anonymous reviewers and Nadja El Benni on an earlier version of the manuscript.

\section{References}

Ackrill, R., Kay, A., Morgan, W., 2008. The Common Agricultural Policy and Its Reform: The Problem of Reconciling Budget and Trade Concerns. Can. J. Agr. Econ. 56(4): 393-411. 
Bhaskar, A., Beghin, J.C., 2009. How Coupled Are Decoupled Farm Payments? A Review of the Evidence. J. Agr. Res. Econ. 34(1): 130-153.

Bielza Diaz-Caneja, M., Conte, C.G., Dittmann, C., Gallego Pinilla, F.J., Stroblmair, J., 2008. Agricultural Insurance Schemes. European Commission, Joint Research Centre.

BLW, 2011. Vernehmlassung zur Agrarpolitik 2014-2017. Federal Office for Agriculture (BLW), Bern, Switzerland.

Cabas, J.H., Leiva, A.J., Weersink, A., 2008. Modeling Exit and Entry of Farmers in a Crop Insurance Program. Agr. Res. Econ. Rev. 37(1): 92-105.

Chakir, R. Hardelin, J., 2010. Crop Insurance and Pesticides in French agriculture: an empirical analysis of multiple risks management. INRA and AgroParisTech Working Papers 2010/04.

Dux, D., Schmid, D., 2010. Grundlagenbericht 2009. Zentrale Auswertung von Buchhaltungsdaten, Forschungsanstalt Agroscope Reckenholz-Tänikon ART, Tänikon, Switzerland.

Efron, B., Gong, G., 1983. A Leisurely Look at the Bootstrap, the Jackknife, and Cross-Validation. Am. Stat. 37(1): 36-48.

El Benni, N, Lehmann, B., 2010. Swiss agricultural policy reform: landscape changes in consequence of national agricultural policy and international competition pressure. In $\mathrm{J}$. Primdahl, and S. Swaffield, eds. Globalisation and Agricultural Landscapes - Change Patterns and Policy trends in Developed Countries. Cambridge University Press, Cambridge, pp. 73-94.

El Benni, N., Mann, S., Lehmann, B., 2011. Distributional Effects of Direct Payments in Switzerland. Paper prepared for the 122nd EAAE seminar "Evidence-Based Agricultural and Rural Policy Making: Methodological and Empirical Challenges of Policy Evaluation". Ancona (Italy), February 17-18, 2011. 
Enjolras, G., Sentis, P., 2011. Crop insurance policies and purchases in France. Agric. Econ. 42(4): $475-486$.

Femenia, F., Gohin, A., Carpenter, A., 2010. The Decoupling of Farm Programs: Revisiting the Wealth Effect. Am. J. Agric. Econ. 92(3): 836-848.

Finger, R., Lazzarotto, P., Calanca, P., 2010. Bio-economic assessment of climate change impacts on managed grassland production. Agr. Syst. 103(9): 666-674.

Finger, R., Calanca, P., 2011. Risk Management Strategies to Cope with Climate Change in Grassland Production: An Illustrative Case Study for the Swiss Plateau. Reg. Env. Change, In Press, DOI: 10.1007/s10113-011-0234-9.

Finger, R., El Benni, N., 2011. Farmers' adoption of extensive wheat production - determinants and implications. Paper prepared for the 122nd EAAE seminar "Evidence-Based Agricultural and Rural Policy Making: Methodological and Empirical Challenges of Policy Evaluation". Ancona (Italy), February 17-18, 2011.

Finger, R., Hediger, W., Schmid, S., 2011. Irrigation as Adaptation Strategy to Climate Change: A Biophysical and Economic Appraisal for Swiss Maize Production. Climatic Change: 105(34): 509-528.

Garrido, A., Zilberman, D., 2008. Revisiting the Demand for Agricultural Insurances: The Case of Spain. Agric. Financ. Rev. 68(1): 43-66

Häusler, L., 2010. Entscheidungsprozesse im landwirtschaftlichen Pachtlandmarkt. Yearbook of Socioeconomics in Agriculture 2010: 401-421.

Hennessy, D.A., 1998. The Production Effects of Agricultural Income Support Policies under Uncertainty. Am. J. Agric. Econ. 80(1): 46-57.

Johnston, J., DiNardo, J., 1997. Econometric Methods. McGraw-Hill, New York. 
Jung, J., Wedon, R., VanSickle, J., 2005. Specialty Crop Producers' Crop Insurance Decisions. Paper prepared for the Southern Agricultural Economics Association Annual Meeting, Little Rock, Arkansas, February 5-9, 2005.

Koundouri, P., Laukkanen, M., Myyrä, S., Nauges, C., 2009. The effects of EU agricultural policy changes on farmers' risk attitudes. Eur. Rev. Agric. Econ. 36: 53-77.

Lemons, H. ,1942. Hail in American Agriculture. Econ. Geogr. 18(4): 363-378.

LID, 2005. Schweizer Hagel - 125 Jahre im Dienst der Landwirtschaft. Dossier 408. Landwirtschaftlicher Informationsdienst (LID), Bern, Switzerland.

Mahul, O., 2003. Hedging price risk in the presence of crop yield and revenue insurance. Eur. Rev. Agr. Econ. 30(2): 217-239.

Mann, S., 2003. Doing it the Swiss Way. EuroChoices 2(3): 32-35.

Mann, S., 2005. Farm size growth and participation in agri-environmental schemes: A configural frequency analysis of the Swiss case. J. Agr. Econ. 56: 373-384.

Mann, S., 2007. Tracing the process of becoming a farm successor on Swiss family farms. Agriculture and Human Values 24 (4): 435-43.

Medina, F., Garrido, A., Iglesias, A., 2010. Analysis of Spanish olive producers' insurance behavior. Paper presented at EAAE/CREDA Workshop on Decisions and choices under uncertainty in Agro-food and Natural Resource Economics. Barcelona, 1st - 2nd July 2010.

Meier, B., 2005. Analyse der Repräsentativität im schweizerischen landwirtschaftlichen Buchhaltungsnetz. Messung und Verbesserung der Schätzqualität ökonomischer Kennzahlen in der Zentralen Auswertung von Buchhaltungsdaten. PhD Dissertation No. 15868, ETH Zurich, Switzerland. 
Musshoff, O., Odening, M., Xu, W., 2011. Management of climate risks in agriculture-will weather derivatives permeate? Appl. Econ. 43(9): 1067-1077.

Ogurtsov, V.A., van Asseldonk, M.A.P.M., Huirne, R.B.M., 2006. Factors Explaining Farmers’ Insurance Purchase in the Dutch Dairy Sector. Paper prepared for the 99th EAAE seminar "Trust and Risk in Business Networks". Bonn (Germany), February 8-10, 2006.

Reardon, T., Taylor, J.E., Stamoulis, K., Lanjouw, P., Balisacan, A., 2000. Effects of Non-Farm Employment on Rural Income Inequality in Developing Countries: An Investment Perspective. J. Agr. Econ. 51(2): 266-288.

Rydant, A.L., 1979. Adjustments to natural hazards: Factors Affecting the Adoption of Crop-Hail Insurance. Prof. Geogr. 31(3): 312-320.

SBV, 2010. Statistische Erhebungen und Schätzungen über Landwirtschaft und Ernährung. Schweizer Bauernverband (SBV, Swiss Farmers’ Union), Brugg, Switzerland.

Schiesser, H.H., 2003. Hagel. In: OcCC, ed. Extremereignisse und Klimaänderung. OcCC - organe consultatif sur les changements climatiques, Bern, Switzerland.

Schiesser, H.H., Schmid, W., 2005. Monitoring von starken Hagelstürmen in der Schweiz 20012002. Stallikon, Switzerland.

Sckokai, P., Moro, D., 2006. Modelling the Reforms of the Common Agricultural Policy for Arable Crops Under Uncertainty. Am. J. Agr. Econ. 88(1):43-56.

Sherrick, B.J., Barry, P.J., Ellinger, P.N., Schnitkey, G.D., 2004. Factors influencing farmers' crop insurance decisions. Am. J. Agric. Econ. 86(1): 103-114.

Torriani, D.S., Calanca, P., Beniston, M., Fuhrer, J. 2008. Hedging with Weather Derivatives to Cope with Climate Variability and Change in Grain Maize Production. Agr. Finance Rev. 68(1): 67-81. 
van Asseldonk, M.A., Meuwissen, M., Huirne, R., 2002. Belief in Disaster Relief and the Demand for a Public-Private Insurance Program. Rev. Agr. Econ. 24(1): 196-207.

Wixon, L.G., 2005. Hail. In: J.E. Oliver, ed. Encyclopedia of World Climatology, Springer, Berlin, pp. $399-402$.

Woldehanna, T., Oude Lansink, A., Peerlings, J., 2000. Off-farm work decisions on Dutch cash crop farms and the 1992 and Agenda 2000 CAP reforms. Agric. Econ. 22: 163-171. 


\section{Table 1. Definition of Variables and Associated Hypotheses}

\section{Dependent Variable \\ Use of Hail \\ Insurance \\ $A_{j}=1$ if farm $i$ used hail insurance in year \\ $\mathrm{j}$, else $\mathrm{A}=0$}

Explanatory Variables

Farm Size

Total size of agricultural land (in ha)

Arable Land

Size of the arable land (in ha)

Share of Arable

Land

Age

Land Tenure

Share of Direct

Payments

Specialization in

Crop Production

Share of Off-Farm

Income

Share of Special

Crops

Education

Dummy 1995

Hail Risk
Share of arable land to total farm size in \%

Age of farm-head in years

Share of owned to total farm land in \%

Share of direct payments to total farm revenue in $\%$

Share of revenue from crop production to total farm revenue in $\%$

Share of off-farm income to total farm revenue in \%

Share of revenue from special crops (e.g. for vine, fruits, vegetables, berries) to total farm revenue in $\%$

Is only reported since 2003. The used levels range from 1 (no agricultural education) to 7 (university degree)

Dummy for the year 1995, the year after the main hail event in 1994 (Schiesser, 2003)

Number of years with hail events for each municipality in the period 1961-2004.

\section{Hypothesis}

Users have a larger farm size, more arable land and a larger share of arable land (e.g. Rydant, 1979, Sherrick et al., 2004)

Users are older (e.g. Sherrick et al., 2004)

Users are less tenured, i.e. have more rented land (e.g. Sherrick et al., 2004)

Non-Users have a higher share of direct payments (based on e.g. Hennessy, 1998)

Users are more specialized in crop production (in contrast to animal or grassland production)

Non-Users have a higher share of off-farm income (e.g. Sherrick et al., 2004)

Users have more special crops that have a higher per area revenue (e.g. van Asseldonk et al., 2002, Lemons, 1942)

Users are better educated (e.g. Sherrick et al., 2004)

Adoption rates are higher after a major hail event (Rydant, 1979)

Users have faced a higher hail risk in the past (e.g. Rydant, 1979) 
Table 2. Mean of Farm and Farmer Characteristics of Insurance Users and Non-Users in 1990, 1999 and 2008

\begin{tabular}{|c|c|c|c|c|c|c|}
\hline \multirow[b]{2}{*}{ Variable } & \multicolumn{2}{|c|}{1990} & \multicolumn{2}{|c|}{1999} & \multicolumn{2}{|c|}{2008} \\
\hline & Users & $\begin{array}{l}\text { Non- } \\
\text { Users }\end{array}$ & Users & $\begin{array}{l}\text { Non- } \\
\text { Users }\end{array}$ & Users & $\begin{array}{l}\text { Non- } \\
\text { Users }\end{array}$ \\
\hline Total Farm Size (in ha) & $18.23 * * *$ & 17.09 & $19.54 * * *$ & 17.65 & $23.06 * * *$ & 20.25 \\
\hline Arable Land (in ha) & $8.48 * * *$ & 4.66 & $7.75 * * *$ & 4.63 & $9.38 * * *$ & 5.03 \\
\hline Share of Arable Land (in \%) & $44.24 * * *$ & 26.09 & $38.53 * * *$ & 24.06 & $37.58 * * *$ & 22.35 \\
\hline $\begin{array}{l}\text { Specialization in Crop Production } \\
\text { (in \%) }\end{array}$ & $23.34 * * *$ & 9.93 & $16.34 * * *$ & 5.92 & $15.14^{* * *}$ & 5.41 \\
\hline Share of Off-Farm Income (in \%) & $7.96 * * *$ & 10.23 & $10.83 * * *$ & 14.36 & $11.61 * * *$ & 15.67 \\
\hline Share of Direct Payments (in \%) & $5.01 * * *$ & 10.11 & $20.12 * * *$ & 29.46 & $22.08 * * *$ & 31.71 \\
\hline Land Tenure (in \%) & $55.12^{* * *}$ & 49.90 & $58.30 * * *$ & 55.28 & $60.08 * * *$ & 54.78 \\
\hline Age (in years) & $42.43 * * *$ & 41.50 & $44.46^{* *}$ & 43.52 & $46.71 *$ & 46.11 \\
\hline Share of Special Crops (in \%) & $4.82 * * *$ & 3.72 & $3.32 * * *$ & 2.01 & $3.58 * * *$ & 1.96 \\
\hline Hail Risk [0-44] & 26.54 & 25.55 & $27.08 * * *$ & 24.78 & $26.26 * *$ & 24.70 \\
\hline Education [1-7] & --- & --- & --- & --- & $3.34 * * *$ & 3.03 \\
\hline Number of Observations & 2763 & 1245 & 1854 & 1220 & 2010 & 1366 \\
\hline
\end{tabular}


Table 3. Results from the Logistic Regressions for the Years 1990, 1999 and 2008.

\begin{tabular}{|c|c|c|c|}
\hline Variable & 1990 & 1999 & 2008 \\
\hline Intercept & $0.371(4.06)^{* * *}$ & $0.262(4.08)^{* * *}$ & $0.297(3.11)^{* * *}$ \\
\hline Farm Size & $1.029(4.82)^{* * *}$ & $1.033(5.09)^{* * *}$ & $1.035(7.01)^{* * *}$ \\
\hline Specialization in Crop Production & $1.043(12.94)^{* * *}$ & $1.058(11.55)^{* * *}$ & $1.045(10.69)^{* * *}$ \\
\hline Off-Farm Income & $1.000(0.33)$ & $1.001(0.16)$ & $1.003(1.34)$ \\
\hline Direct Payments & $0.960(5.95)^{* * *}$ & $0.972(6.00)^{* * *}$ & $0.969(7.47)^{* * *}$ \\
\hline Land Tenure & $1.003(2.48)^{* *}$ & $1.001(0.58)$ & $1.005(2.87)^{* * *}$ \\
\hline Age & $1.004(1.07)$ & $1.017(3.26)^{* * *}$ & $1.007(1.36)$ \\
\hline Hail Risk & $1.025(5.81)^{* * *}$ & $1.023(5.01)^{* * *}$ & $1.015(3.52)^{* * *}$ \\
\hline Education & --- & --- & $1.128(2.00)^{* *}$ \\
\hline Number of Observations & 3260 & 2416 & 2677 \\
\hline Correct Predictions $^{1}$ & $75.64 \%$ & $72.76 \%$ & $71.46 \%$ \\
\hline
\end{tabular}

Numbers in parentheses are z-values. 1) Based on 1000 replications of a cross validation procedure. 
Table 4. Results from the Logistic Regression Using Panel Data 1990-2009

\begin{tabular}{llll}
\hline Variable & Model 1 & Model 2 & Model 3 \\
Intercept & $0.524(4.31)^{* * *}$ & $1.327(4.37)^{* * *}$ & $1.633(4.00)^{* * *}$ \\
Farm Size & $1.065(18.86)^{* * *}$ & --- & $1.066(22.85)^{* * *}$ \\
Specialization in Crop Production & $1.071(33.93)^{* * *}$ & $1.016(19.53)^{* * *}$ & --- \\
Off-Farm Income & $0.996(4.72)^{* * *}$ & $1.000(1.01)$ & $0.999(2.07)^{* *}$ \\
Direct Payments & $0.961(22.27)^{* * *}$ & $0.992(11.78)^{* * *}$ & $0.952(33.39)^{* * *}$ \\
Hail Risk & $1.041(9.05)^{* * * *}$ & $1.014(6.58)^{* * *}$ & $1.030(8.01)^{* * *}$ \\
Dummy: 1995 & $1.434(7.55)^{* * *}$ & $1.065(3.63)^{* * *}$ & $1.348(7.50)^{* * *}$ \\
Number of Observations & & 60810 from 8804 farms \\
\hline Correct predictions & & $86.52 \%$ & $90.50 \%$ \\
\hline Numbers in parentheses are t-values. 1) Based on 1000 replications of a cross validation procedure
\end{tabular}


Table 5. Results from the Logistic Regression Using Panel Data 2003-2009

\begin{tabular}{llll}
\hline Variable & Model 1 & Model 2 & Model 3 \\
Intercept & $0.087(5.48)^{* * *}$ & $0.470(1.77)$ & $0.124(5.34)^{* * *}$ \\
Farm Size & $1.098(14.20)^{* * *}$ & --- & $1.099(16.42)^{* * *}$ \\
Specialization in Crop Production & $1.063(16.12)^{* * *}$ & $1.069(17.32)^{* * *}$ & --- \\
Off-Farm Income & $0.997(2.33)^{* *}$ & $0.994(4.04)^{* * *}$ & $1.001(0.50)$ \\
Direct Payments & $0.966(8.38)^{* * *}$ & $0.975(6.26)^{* * *}$ & $0.963(10.08)^{* * *}$ \\
Hail Risk & $1.060(7.28)^{* * *}$ & $1.048(5.95)^{* * *}$ & $1.053(7.20)^{* * *}$ \\
Education & $1.360(2.99)^{* * *}$ & $1.520(4.09)^{* * *}$ & $1.528(4.74)^{* * *}$ \\
Dummy: 1995 & --- & --- & --- \\
Number of Observations & & 80164 from 4776 farms & $86.49 \%$ \\
Correct predictions & & &
\end{tabular}

$\overline{\text { Numbers in parentheses are t-values. 1) Based on } 1000 \text { replications of a cross validation procedure. }}$ 
Figure 1. Development of hail insurance adoption, the share of direct payments and off-farm income to total farm revenue as well as of farm size and arable land, 1990-2009
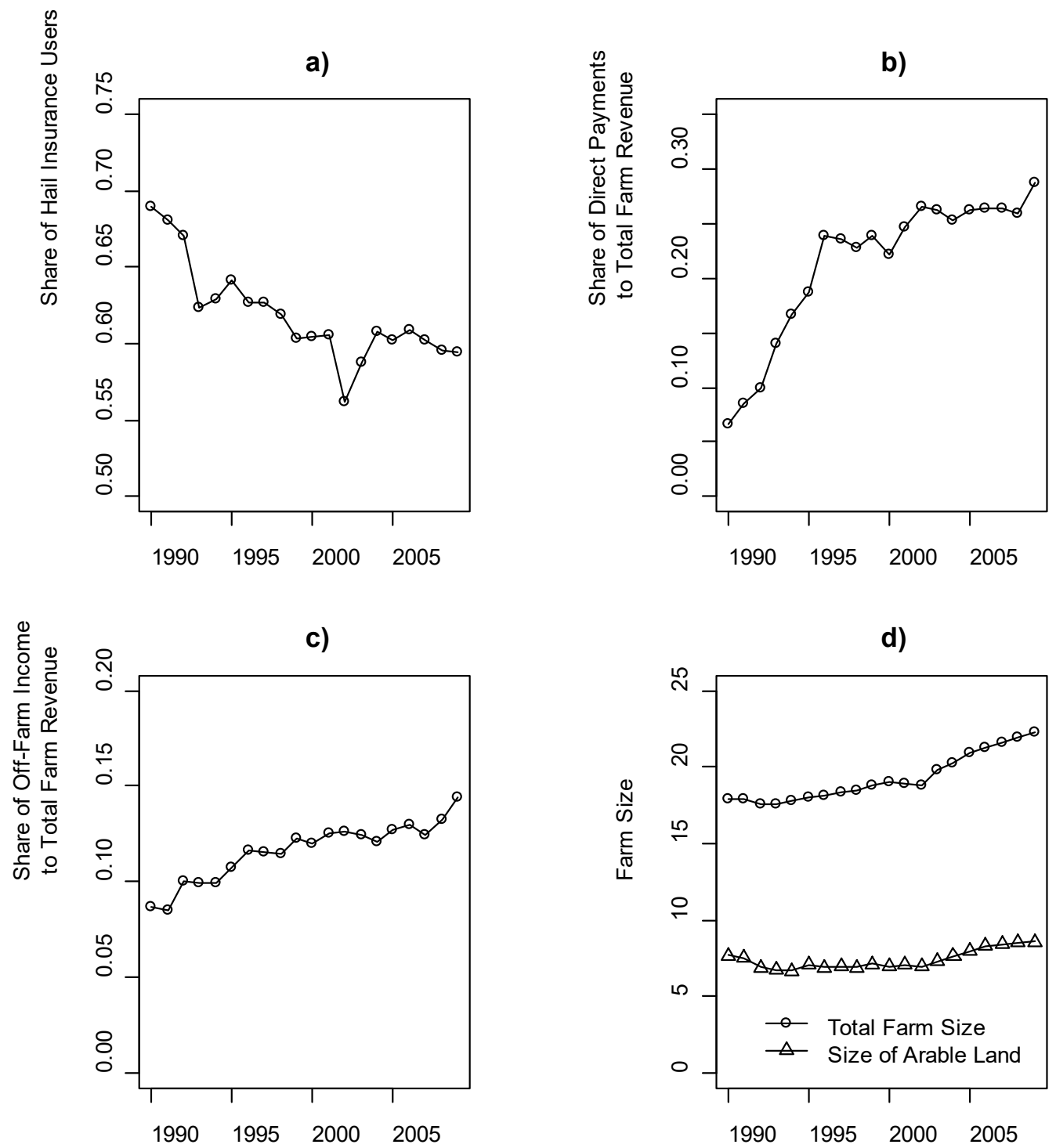

d)

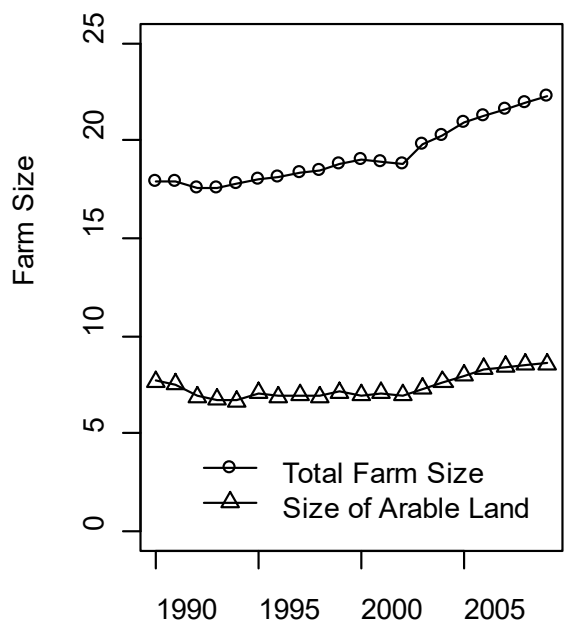


Figure 2. Hail hazards in Switzerland in the period 1961-2004

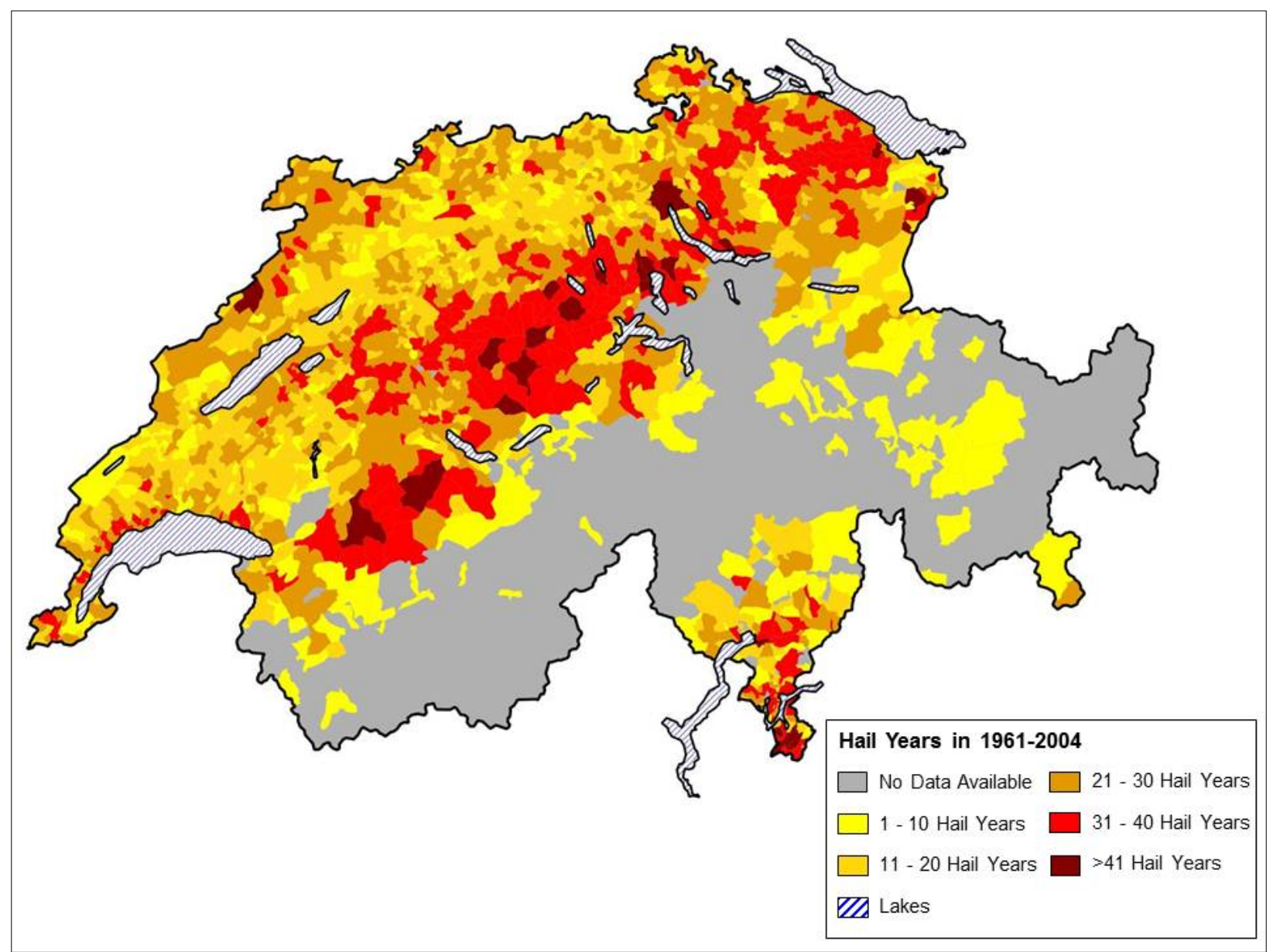


Figure 3. Spatial distribution of hail insurance adoption rates and the share of direct payments to total farm revenue in Switzerland in the years 1990 and 2008

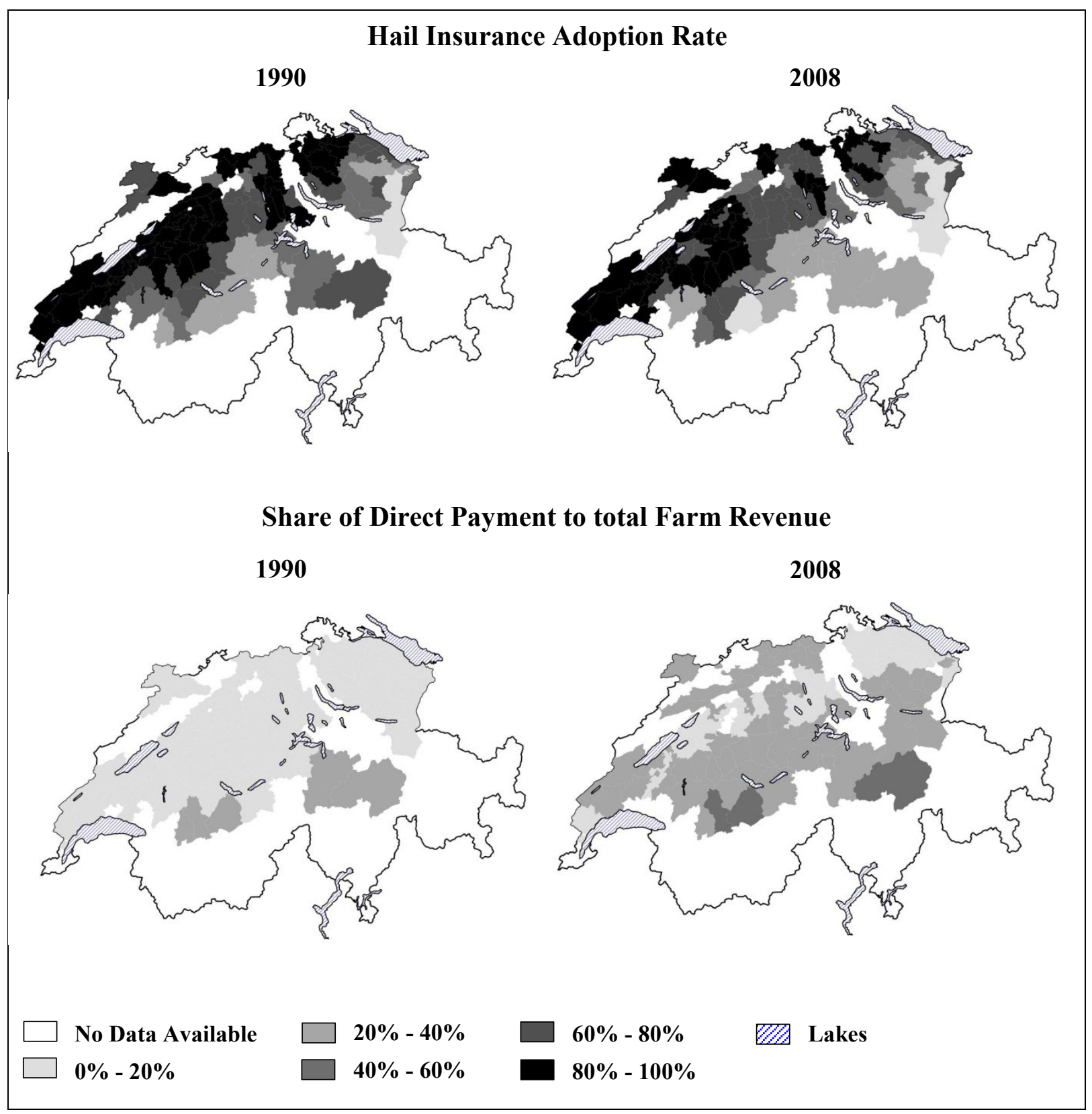


Figure 4. Marginal effects of different explanatory variables on the probability of hail insurance adoption (for the 1990, 1999 and 2008 model).
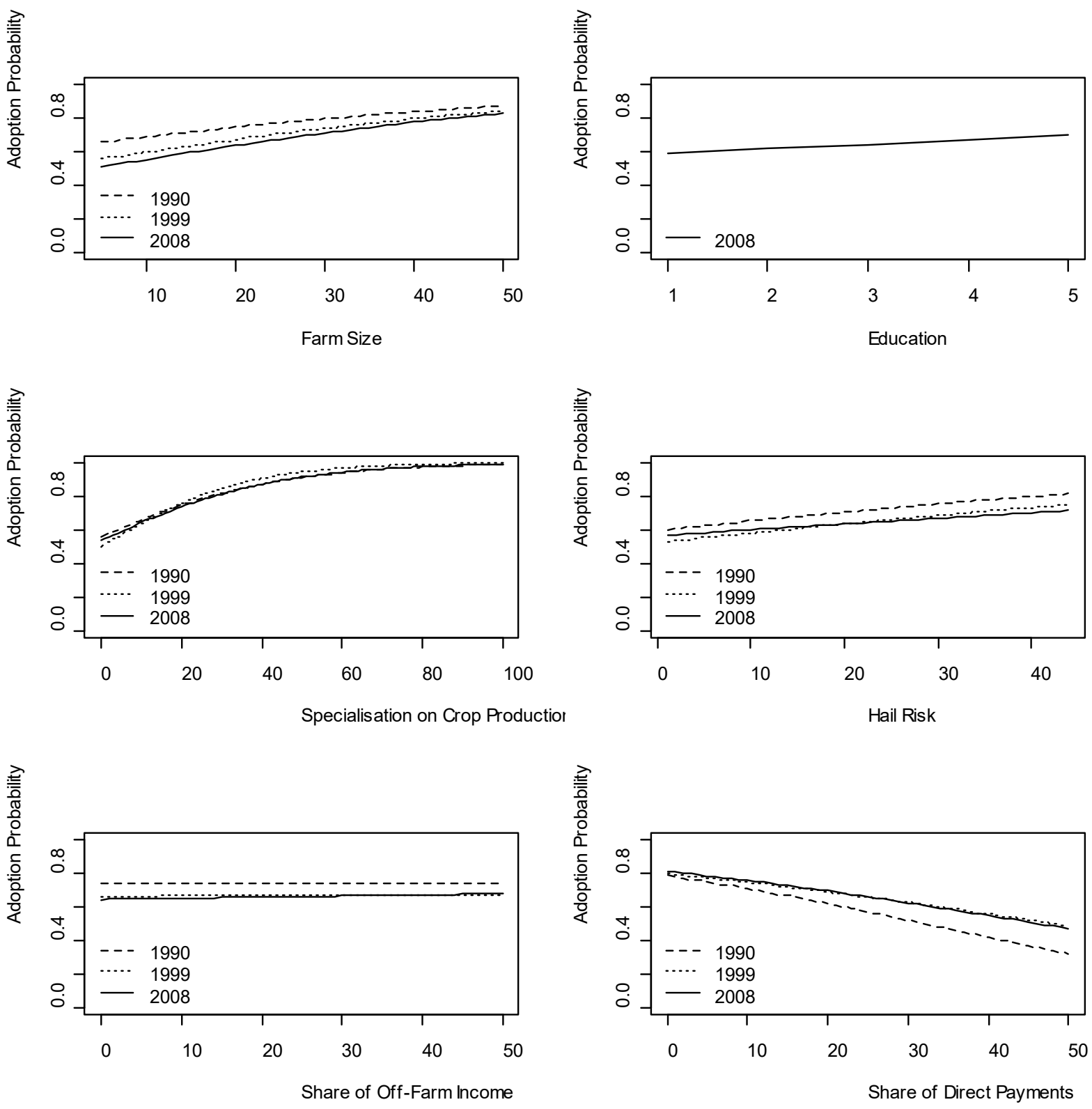